\title{
Combinatorial functions of two chimeric antibodies directed to human CD4 and one directed to the $\alpha$-chain of the human interleukin-2 receptor
}

(Recombinant DNA; transfectoma technology; complement activation; antigen modulation; mAb cocktail; mixed lymphocyte reaction)

\author{
Winfried Weissenhorn ${ }^{a, *}$, Werner Scheuer ${ }^{b}$, Brigitte Kaluza ${ }^{b}$, Marina Schwirzke ${ }^{b}$, Christian Reiter ${ }^{a}$, \\ Dimitri Flieger ${ }^{\text {a }}$, Helmut Lenz ${ }^{c}$, Elisabeth H. Weiss ${ }^{a}$, Ernst Peter Rieber ${ }^{\mathrm{a}}$, Gert Riethmüller ${ }^{\mathrm{a}}$ and \\ Ulrich H. Weidle ${ }^{b}$
}

\begin{abstract}
"Institut für Immunologie der Universität München, W-8000 Munich, Germany. Tel. (49-89)5996-689; ' Boehringer Mannheim. GmbH, Department of Biotechnology, W-8122 Penzberg, Germany; ${ }^{\mathrm{c}}$ Biochemical Research Center, Boehringer Mannheim, GmbH, W-8132 Tutzing, Germany. Tel. (49-8158j22420
\end{abstract}

Received by H.G. Zachau: 21 April 1992; Accepted: 16 June 1992; Received at publishers: 14 July 1992

\section{SUMMARY}

The general feasibility of chimerization of monoclonal antibodies (mAbs) has already been shown for a large number of them. In order to evaluate in vitro parameters relevant to immunosuppressive therapy, we have chimerized and synthesized two anti-CD4 mAbs recognizing two different epitopes on the human T-lymphocyte antigen, CD4. The chimerized mAbs are produced at levels corresponding to those of the original hybridoma cell lines. With respect to activation of human complement, the individual Abs are negative; however, when used in combination, complement activation was performed. When applied in combination, they were found to modulate the CD4 antigen, whereas the individual mAb do not display this property. Individually they mediate an up to $60 \%$ inhibition of the mixed lymphocyte reaction (MLR). However, by combination of an anti-CD4 $\mathrm{mAb}$ with one directed against the $\alpha$-chain of the human IL2 receptor, nearly $100 \%$ inhibition of the MLR was achieved, even with reduced dosage of the mAbs. Our data suggest that the combination of an anti-CD4 $\mathrm{mAb}$ and an anti-IL2R $\alpha$ chain $\mathrm{mAb}$ is more effective with respect to immunosuppression than each mAb by itself, indicating that this mAb cocktail could be a new strategy for immunosuppressive therapy.

Correspondence to: Dr. U.H. Weidle, Department of Biotechnology, Boehringer Mannheim, GmbH, Nonnenwald 2, Postfach 1152, W-8122 Penzberg, Germany. Tel. (49-8856)60-2801; Fax (49-8856)60-2659.

* Present address: Howard Hughes Medical Institute, Laboratory of Molecular Medicine, 300 Longwood Ave., Boston, MA, USA.

Tel. (617)735-7373; Fax (617) 730-0506.

Abbreviations: aa, amino acid(s); Ab, antihody; cDNA, DNA complementary to mRNA; CDR, complementarity-determining regions; CD4, T-cell surface antigen; D, diversity regions; Fab, antigen-binding fragments of Abs that are derived by papain digestion and contain the $\mathrm{L}$ chain and part of the $\mathrm{H}$ chain (variable region and first constant region); FACS, fluorescence-activated cell sorting; FITC, fluorescein isothiocyanate; $H$, heavy chain of $\mathrm{Ab}$; Ig, immunoglobulin; IL2, interleukin 2; IL2R, IL2 receptor; IL2R $\alpha, \alpha$ chain of IL2R; J, joining region; kb, kilobase(s) or $1000 \mathrm{bp} ; \mathrm{L}$, light chain of $\mathrm{Ab} ; \mathrm{mAb}$, monoclonal $\mathrm{Ab}$; MES, morpholinoethanol-sulfonic acid; MLR, mixed lymphocyte reaction; $n t$, nucleotide(s); PBL, peripheral blood lymphocytes; PBS, phosphate-buffered saline (0.15 M NaCl/10 mM Na.phosphate $\mathrm{pH} 7.5$ ); PCR, polymerase chain reaction; RPMI, Roswell Park Memorial Institute (medium); $V$, gene (DNA) encoding V; VDJ, variable region of rearranged $H$ chain; $V_{H}$, variable region of heavy chain; $\mathrm{VJ}$, variable region of rearranged $\mathrm{L}$ chain; $V_{L}$, variable region of light chain. 


\section{INTRODUCTION}

Antibodies that recognize antigens on the surface of human lymphocytes have been used as immunosuppressive agents for more than 20 years. Since the development of techniques to produce mAb (Köhler and Milstein, 1975)

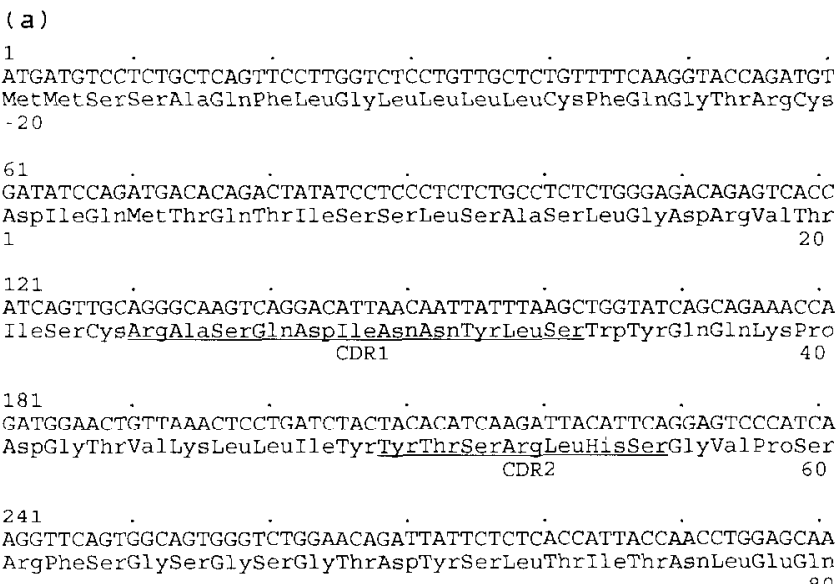

301 GAAGATGTTGCCACTTACT'TTTGCCAACAGGGTAATACGCTTCCGTACACGTTCGGAGGG GluAspvalAlaThrTyrpheCysGlnGinGlyAsnThrLeuproTyrThrPheGlyGly $\mathrm{CDR} 3$ 100

361

GGGACCAAGCTGLAAATAAAA

GlyThrLysLeuGluIleLys
107

(c)

ATGGAGACAGACACAATCCTGCTATGGGTGCTGCTGCTCTGGGTTCCAGGCTCCACTGGT MetGluThrAsp'ThrIleLeuLeuTroval LeuLeuLeuTrpVal ProGlyserThrGly -20
$-20 t g$

61

GACATTGTGCTGACCCAATCTCCAGCTTCTTTGCCTATGTCTCTAGGGCAGAGGGCCACC AspIl eVal TeuThrGlnserproAlaserteuProMet Sert,enGl YGl nA rgA 1 aThr 1

121 ATCTCCTGCAAGGCCAGCCAAAGTCTTGATTATGATGGTGATAGTTATATGAACTGGTAC IleSerCysLysAlaserGlnSerLeuAspTyrAspGlyAspSerTyrMetAsnTrpTyr

181 CAACAGAAACCAGGACAGCCACCCAAACTCCTCATCTATGCTGCATCCAATCTAGAATCT GlnGlnLysProGlyGlnProProLys LeuLeuIleTyrAlaAlaserAsnLeuGluSer

241

GGGATCCCAGCCAGATTTAGTGGCAGTGGGTCCGGGACAGACTTCACCCTCAACATCCAं GlyIleproAldArgPheSerGly SerGly SerGlyThrAspPheThr LeUAsmI eH is

301 CCTGTGGAGGAGGAGGATGCTGCAACCTATTACTGTCAGCAAAGTAGTGAGGATCCTCCG ProvalGl uGluGluAspalaAlaThrTyrTyrCysGlnGlnSerSerGluAspProPro

362

ThrPheGlyGlyGlyThrLYsLeuGluIleLys that recognize a variety of antigens on the lymphocyte surface, mAbs are clinically applied for the diagnosis and ther-apy of an array of human disorders. Possible targets for immune intervention focus on two antigens expressed by $\mathrm{T}$ lymphocytes. CD4 is only expressed by a subset of $\mathrm{T}$ lymphocytes. This phenotype is usually, but not exclusively, (d)

ÁTGGAATGGÄGGATCTTTCTCTTCATCCTGTCAGGAACTGCAGGTGTCCACTCCCAGGTT MetGluTrpArgIlepheLeuPheI leLeuSerGl y ThrAlaGlyValHisSerGlnVal MetGluTrpArgIlepheLeuPheIleLeuSerGIYThrAlaglyvalHisSerG
-18 61 CACCTGCAGCAGTCTGGACCTGAGCTGGTGAAGCCTGGGCCTTCAGTGAAGATGTCCTGC H i st,eugl nGl nGerGly ProGl uLeuVal LysProGlyProserVal LysMet SerCys 121 AAGCTTCTGGATACACATTCACTGACTATGTTGTAAGTIGGATGCAACAGAGAACTGGA LysAlaSerGlyTyrThrPheThrAspTyrValValSerTrpMetGlnGlnArgThrGly 181 CAGGTCCTTGAGTGGATTGGAGAGATTATCCTGGAAGTGGTAGTGCTTATTACAATGAA GlnVal LeuGluTrpIleGlyGluI le TyrProGlySerGlySerAla TyrTyrAsnglu

241

AAATTCAAGGGCAAGGCCATACTGACTGCAGACAAATCCTCCAGCACAGCCTACATGGAG

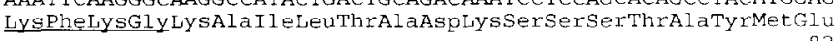

301 TTCAGCAGCCTGACATCTGAGGACTCTGCGGTCTTTTTCTGTGCAAGACGGGGGGATGGI FheSerSerLeuThrSerGluAspSerAlaval phePheCysAlaArgArgGly AspGly

361 TCCCTCGGCTTTGCTCACTGGGGCCAAGGGACTCTGGTCAGTGTCGCTGCA SerLeuGlyPheAlaHisTrpGlyGlnGlyThrLeuvalservalAlaAla 119

Fig. 1. Sequences of (a) L and (b) H chains of mAb M-T151 and (c) L and (d) H chains of mAb M-T310. The CDR regions (Kabat et al., 1987) are underlined. The numbers below the sequence indicate aa positions; 1 indicates the first aa of the mature protein; upstream aa represent the signal sequence. The numbers on the left margin specify the $\mathrm{nt}$ positions, with $\mathrm{nt}=1$ corresponding to the $\mathrm{A}$ of the ATG start codon. In (a) the $\mathrm{J}_{2}$ region of the L chain of mAb M-T151 is from Tyr ${ }^{96}$ to Lys ${ }^{107}$, in (b) the $J_{4}$ region of the $H$ chain is from Asp ${ }^{108}$ to Ser ${ }^{120}$, in (c) the $J_{1}$ region of the $I_{\text {. chain of }} \mathrm{mAh}$ M-T310 is from $\mathrm{Thr}^{101}$ to Lys ${ }^{111}$, in (d) the $\mathrm{J}_{3}$ region of the $\mathbf{H}$ chain is from His ${ }^{107}$ to Ala ${ }^{118}$. Methods. RNA was isolated from $1 \times 10^{7}$ hybridoma cells secreting mAbs M-T151 and M-T310 and selected for poly(A) ${ }^{+}$RNA on oligo(dT) cellulose (Maniatis et al., 1982). cDNA was synthesized with the BRL cDNA synthesis kit according to the instructions of the supplier and the sequences determined by the dideoxy method (Sanger et al., 1977; Weissenhorn et al., 1991). 
associated with helper/inducer $\mathrm{T}$ cell functions such as promoting immunoglobulin production and cytotoxicity. It has been shown that $\mathrm{mAb}$ targeting of $\mathrm{CD} 4 \mathrm{~T}$ cells induced profound humoral and cellular immunological unresponsiveness. The experimental findings in the mouse system (Cobbold et al., 1984; Miller et al., 1985) have led to clinical evaluation of anti-CD4 mAbs in the serotherapy of diseases (Herzog et al., 1987; Reiter et al., 1991; Reinke et al., 1991). The IL2R is a target of considerable interest, particularly as it is an activation antigen, composed of an inducible $\alpha$ chain $(55 \mathrm{kDa})$ and a $\beta$ chain $(75 \mathrm{kDa})$, which only appears on the surface of $\mathrm{T}$ lymphocytes when they are activated by antigen or mitogen. Successful therapeutical application of an IL2R mAb has been already shown by different groups (Kyle et al., 1989; Hervé et al., 1990; Waldmann, 1991a).

Since there are limitations to administering non-human proteins, efforts to engineer new generations of antibodies are underway and are directed towards making the antibodies more human-like, with the aim of lowering the immunogenicity of these proteins in man and optimizing their physiological effector functions and pharmacokinetic characteristics. One approach to decrease mAb immunogenicity (Morrison et al., 1984) is the synthesis of chimeric mAb. After the demonstration that lymphoid cells can express cloned, transfected Ig genes, mouse/human chimeric mAbs were generated with specificities directed towards a wide range of tumour antigens and $\mathrm{T}$-cell surface molecules. The benefits of chimeric mAb for serotherapy in humans are widely accepted.

A

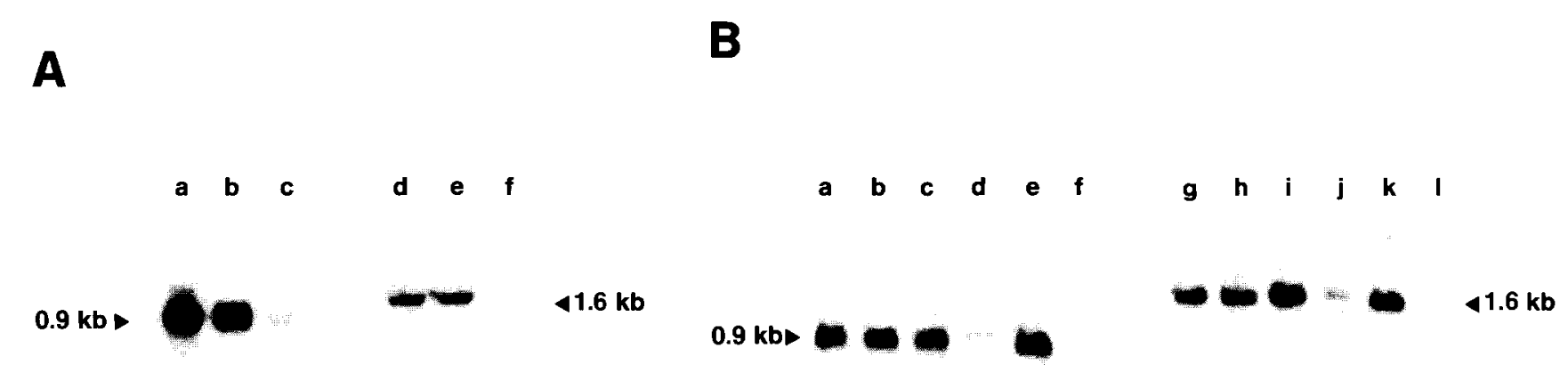

The aim of this work was to generate chimeric mouse/ human antibodies directed against the T-cell antigen CD4. Furthermore, the chimeric mAbs M-T310 and M-T151 were analysed alone and in combination with MAK 179, an IL2R $\alpha$ chimeric mAb (Kaluza et al., 1991), with respect to their physiological effector functions. With the aim of possible clinical application, we have evaluated in vitro possible synergistic effects between the two anti-CD4 mAb M-T310 and M-T151, recognizing two different epitopes on the first and second extracellular domains of the T-cell surface glycoprotein CD4 (Peterson and Seed, 1988; Sattentau et al., 1989; Ashkenazi et al., 1990), and combinations of the two anti-CD4-specific chimeric mAbs with the IL2R $\alpha$-specific chimeric mAb MAK 179.

\section{RESULTS AND DISCUSSION}

\section{(a) Cloning and sequence analysis of $\mathrm{V}$ region sequences}

The functionally rearranged $V_{H}$ and $V_{L}$ regions of mAbs M-T310 and M-T151 have been cloned and subsequently fused to human constant region gene segments encoding the human $\gamma 1$ chain (vector pUHW $\gamma 1$ ) and human $\kappa$ chain (vector pUHW $\kappa$ ), as described (Weissenhorn et al., 1991). The $n t$ and the deduced aa sequences of anti-CD4 mAb V and $V_{L}$ regions are shown in Fig. 1. Both the $V_{H}$ and $V_{L}$ sequences of anti-CD4 mAbs M-T310 and M-T151 show no significant homology with respect to their nt and aa sequences. The $V_{\mathrm{H}}$ region genes can be attributed to two different $V_{\mathrm{H}}$ gene families according to previously defined

Fig. 2. Northern blot analysis of hybridomas and transfectomas secreting murine and chimeric mAb M-T151 and M-T310. Panel A displays the analysis of $\kappa$ and $\gamma$ transcripts for mAb M-T310: lanes a-c $\kappa$ transcripts of mAb M-T310; a, transfectoma; b, hybridoma; c, recipient cell line Sp2/0. Lanes d-f, $\gamma$ transcripts of mAb M-T310. Panel B shows the equivalent analysis for mAb M-T151. The sizes of the detected transcripts are shown in kb. $\kappa$ and $\gamma$ transcripts of mAb M-T151: a-f, $\kappa$ transcripts; $\mathbf{g}-\mathbf{l}, \gamma$ transcripts; a-d, four transfectomas; e, hybridoma; $\mathbf{f}, \mathbf{S p} 2 / 0$, $\mathbf{g}-\mathbf{j}$, four transfectomas corresponding to those in lanes $\mathbf{a}-\mathbf{d} ; \mathbf{k}$, hybridoma; $\mathbf{1}, \mathrm{Sp} 2 / 0$. Methods. Total RNA was extracted from $1 \times 10^{8}$ cells according to the method described by Auffray and Rougeon (1980). Ten $\mu$ g of total RNA was electrophoresed on a $1.2 \%$ agarose gel containing $2.2 \mathrm{M}$ formaldehyde and transferred to a nitrocellulose membrane (Amersham, Braunschweig, Germany) by standard procedures (Maniatis et al., 1982). The blots were hybridized with V-specific probes. For detection of $\kappa$ mRNA a 274-bp EcoRV-NotI fragment was used for M-T151; for M-T310 a 248 -bp KpnI-NotI fragment was used as a probe. The $\gamma$ transcripts were detected with the following probes: a 767-bp StyI fragment for mAb M-T310 and a 367-bp Bam HI-BglII fragment for M-T151. Radioactive probes were obtained by labelling the fragments with $\left[\alpha-{ }^{32} \mathrm{P}\right] \mathrm{dCTP}$ using the random primed DNA-labelling kit supplied by Boehringer Mannheim. Then $2 \times 10^{6} \mathrm{cpm}$ per labelled fragment were used for hybridization, which was performed as described in Maniatis et al. (1982). 
$V_{\mathrm{H}}$ gene families. $V$ gene families comprise groups of related $V$ genes that in general share greater than $80 \%$ sequence similarity (Brodeur and Riblet, 1984; Winter et al., 1985; Kabat et al., 1987). The $V_{\mathrm{H}}$ region gene segment of mAb M-T310 is a member of the J558 gene family, and the $V_{\mathrm{H}}$ region of $\mathrm{mAb} \mathrm{M}-\mathrm{T} 151$ belongs to the VGam gene family. The $V_{\mathrm{H}}$ regions display different $\mathrm{D}$ region segments which have been rearranged either to $\mathrm{J} 3$ or to J4. The heterogeneous nature of the ' $D$ ' sequences makes the precise determination of $\mathrm{V}_{\mathrm{II}}-\mathrm{D}$ and $\mathrm{D}-\mathrm{J}_{\mathrm{II}}$ boundaries impossible. Although none of these somatic D regions corresponds exactly to identified germline $\mathrm{D}$ segments (Kurosawa and Tonegawa, 1982), they all show regions of homology flanked by relatively G-rich sequences ( $\mathrm{N}$ sequences) which have previously been proposed to be inserted during $\mathrm{V}_{\mathrm{H}^{-}}$-D and D- $\mathrm{J}_{\mathrm{H}}$ joining events (Alt and Baltimore, 1982). Similar results were obtained for the $V \kappa$ sequences. M-T310 $\mathrm{V} \kappa$ is a member of the $\mathrm{V} \kappa 21$ subgroup and $\mathrm{V} \kappa \mathrm{M}-\mathrm{T} 151$ of the $\mathrm{V} \kappa 10$ subgroup (Kabat et al., 1987; Kofler et al., 1989; Strohal et al., 1989). V $\kappa$ M-T310 is rearranged to $\mathrm{J} 1$ and $\mathrm{V} \kappa \mathrm{M}-\mathrm{T} 151$, to $\mathrm{J} 2$. This diversity in sequence correlates with their different CD4 antigen binding pattern. Both mAbs recognize different epitopes on the CD 4 molecule as indicated by cross-blocking experiments (data not shown), and they map to different antigenic regions, as shown by mutational analysis of the CD4 molecule (Peterson and Seed, 1988; Sattentau et al., 1989; Ashkenazi et al., 1990).

\section{(b) Synthesis of chimeric mAb M-T151 and M-T310 in transfectomas}

Genomic VJ and VDJ regions of mAbs M-T151 and M-T310 were isolated by the PCR reaction, fused to human $\kappa$ and $\gamma 1$ constant regions, transfected into Sp2/0 cells and stable transformants isolated by G418 selection. Details are described in Weissenhorn et al. (1991). Fig. 2 reveals that transfectants with steady state levels of $\kappa$ - and $\gamma 1$ specific transcripts corresponding in abundance to those of the original hybridoma cells could be isolated after screening about 200 transfectants for each chimeric mAb. This holds true with the exception of the transfectant shown in Fig. 2B, lanes $\mathrm{d}$ and $\mathrm{j}$. With the $\kappa$-specific $\mathrm{V}$ region probe, slight cross-hybridisation to an endogeneous $\kappa$ message in the recipient cell line Sp2/0 was observed (Fig. 2A, lane c). This message contains a premature stop codon and does not mediate synthesis of a secreted, truncated protein $(\mathrm{Ca}-$ billy and Riggs, 1985). Synthesis of murine and chimeric $\mathrm{mAb}$ corresponds to $15-20 \mu \mathrm{g} / \mathrm{ml} / 10^{6}$ cells $/ 24 \mathrm{~h}$. The isolated VJ and VDJ regions contain the authentic introns in the signal sequences of $\mathrm{L}$ and $\mathrm{H}$ chains. Expression of the chimeric genes is mediated by a tandem combination of a $\mathrm{H}$ chain promoter/enhancer element (Weissenhorn et al., 1991). The result indicates that transfectomas with expres- sion levels of chimeric mAb corresponding to those of the original hybridoma can be established with this experimental design without the need to amplify transfected genes.

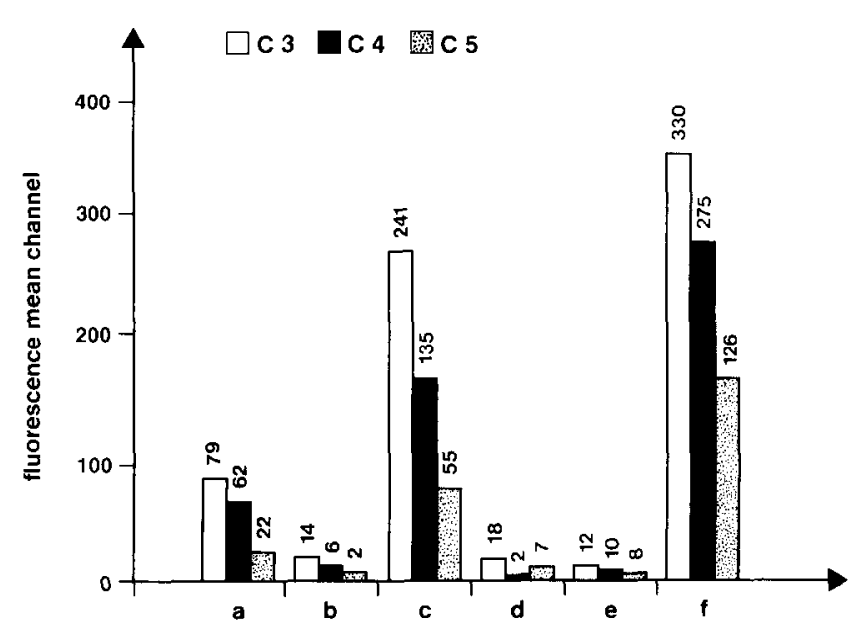

Fig. 3. Activation of human complement by anti-CD4 mAb. Deposition of complement components $\mathrm{C} 3 \mathrm{c}, \mathrm{C} 4$ and $\mathrm{C} 5$ is shown as total fluorescence mean channel after detection by $\mathrm{C} 3$-, $\mathrm{C} 4$ - and $\mathrm{C} 5$-specific FITCconjugated antisera in a FACscan analysis; $\mathbf{a}, \mathrm{m} \mathrm{M}-\mathrm{T} 15 \mathrm{I}\left(\mathrm{IgG}_{2 \mathrm{a}}\right) ; \mathbf{b}, \mathrm{m}$ M-T310 (IgG1); c, m M-T151+m M-T310; d, chim M-T151 (IgG1); e, chim M T310 (IgG1); f, chim M-T151+chim M-T310. Open bars represent $\mathrm{C} 3 \mathrm{c}$, filled bars $\mathrm{C} 4$ and stippled bars $\mathrm{C} 5$. Methods. Hybridomas and transfectomas were fermented in a 10-liter reactor in suspension culture with $5 \%$ FCS. After concentration of the eluate to $700 \mathrm{ml}$, the $\gamma$ globulin fraction was precipitated by adjusting the supernatant to $2 \mathrm{M}$ $\left(\mathrm{NH}_{4}\right)_{2} \mathrm{SO}_{4} \mathrm{pH}$ 7. After dialysis against $10 \mathrm{mM}$ MES buffer $\mathrm{pH} 5.8$, the fraction was applied to an S-Sepharose column (Pharmacia) equilibrated with the same buffer at $4^{\circ} \mathrm{C}$, cluted with a lincar $\mathrm{NaCl}$ gradicnt $(0.1-$ $0.25 \mathrm{M} \mathrm{pH} 5.8$ ), and fractions containing mAbs were pooled. The material was adjusted to $1 \mathrm{M}\left(\mathrm{NH}_{4}\right)_{2} \mathrm{SO}_{4} \mathrm{pH}$, applied to a Protein A Sepharose column (Pharmacia) equilibrated with the same buffer and eluted with $0.1 \mathrm{M} \mathrm{Na}_{3}$.citrate $\mathrm{pH}$ 3.4. After dialysis against PBS buffer $\mathrm{pH} 7.5$ and ultrafiltration, contaminating bovine IgG was removed by adsorption to Spherosil conjugated with sheep anti-bovine IgG. For the complement activation experiments, PBL from EDTA-blood of healthy adults were isolated by Ficoll-Hypaque density centrifugation. Then $1 \times 10^{5} \mathrm{PBL}$ were incubated with $50 \mu \mathrm{l}$ of purified $\mathrm{mAb}(10 \mu \mathrm{g} / \mathrm{ml}$ of each $\mathrm{mAh})$ for $30 \mathrm{~min}$ on ice. After washing twice with ice-cold PBS, $50 \mu$ l of fresh human serum was added to the cells and incubated for $20 \mathrm{~min}$ at $37^{\circ} \mathrm{C}$. For the negative control, mAb-targeted cells were incubated with heat-inactivated serum. The cells were washed twice with ice-cold PBS and subjected to complement component-specific antisera and incubated on ice for $20 \mathrm{~min}$ (for detection of $\mathrm{C} 3 \mathrm{c}$ a rabbit anti-C3c, for $\mathrm{C} 4$ a rabbit anti-C4 FITCconjugated serum and for $\mathrm{C} 5$ a rabbit anti-C5 serum was used; all from Dakopatts). After washing cells twice with PBS, the anti-C3c and antiC5 targeted cells were further incubated with goat anti-rabbit Ig FITCconjugated serum (Dianova) for $20 \mathrm{~min}$ on ice, washed twice with PBS and fixed with $1 \%$ paraformaldehyde. The fluorescence intensity was quantified by FACscan analysis as fluorescence mean channel of living $\mathrm{CD}^{+}$cells on a log scale. The value of the mean channel was obtained by subtraction of the value of the mean channel of the negative control (incubation of CD4-mAb-targeted $\mathrm{T}$ cells with heat-inactivated serum and detection of cells with complement-specific antisera) from total mean channel of positive experiments. 


\section{(c) Complement activation}

As the aim of targeted mAb therapy is either modulation of the CD4 molecule (Lifson and Engleman, 1989) or elimination of reactive $\mathrm{T}$ cells, it was important to evaluate the complement activation properties of our mAbs. Compared with other human Ig subclasses, the greatest effectiveness with respect to physiological effector functions has been described for the IgG1 isotype (Brüggemann et al., 1987; Riechmann et al., 1988). We therefore selected the human IgG1 isotype for chimerization of the anti-CD4 $\mathrm{mAhs}$. The activation of complement was assayed by determination of the ability of the mAbs to induce deposition of components of the complement cascade on the surface of $\mathrm{CD}^{+} \mathrm{PBL}$.

The results show that murine $\mathrm{M}-\mathrm{T} 151\left(\mathrm{IgG}_{2 \mathrm{a}}\right)$ activates human complement weakly (Fig. 3a), whereas murine M-T310 (IgG1) is negative with respect to this property (Fig. 3b). The combination of these murine anti-CD4 mAbs results in a dramatic enhancement of activation of human complement (Fig. 3c). The chimeric mAbs M-T151 (IgG1) and M-T310 (IgG1) do not display human complementactivating properties (Fig. 3d,e) by themselves; however, a combination of these mAbs results in complement activation stronger than the activation induced by a combination of the murine $\mathrm{mAb}$ (Fig. 3f). As a negative control, mAbtargeted cells have been incubated with heat-inactivated serum. Consistently, only background levels of fluorescence intensity have been observed (data not shown). Unfortunately, a lytic $\mathrm{mAb}$ pair was not available for our studies. Synergy with respect to complement activation for pairs of
mAbs has also been shown by Bindon et al. (1985) and Hughes-Jones et al. (1983).

\section{(d) Immunomodulation by chimeric anti-CD4 mAbs}

To determine the possible role of modulation of $\mathrm{CD}^{+}$ cells rather than elimination of these cells, the effect of anti-CD4 mAbs on whole blood cells was determined. Fig. 4 shows the result of these experiments. The blood of both donor A and donor B did not show any effect when coculturing the whole hlood with only one chimeric anti$\mathrm{CD} 4 \mathrm{mAb}$ alone. The amount of $\mathrm{CD} 4^{+}$cells from time point 0 until $48 \mathrm{~h}$, differentiating into total CD4, highexpressing and low-expressing cells, resulted in the same graphs in the control samples as well as in the samples containing either the anti-CD4 mAb M-T310 or M-T151. There is no significant decrease of $\mathrm{CD} 4^{+}$cells induced by the chimeric anti-CD4 mAb. By adding both anti-CD4 mAbs, M-T310 and M-T151, the CD4 level changes from time point 0 to $48 \mathrm{~h}$. Samples of both blood donors show a $90 \%$ (A) and $70 \%$ (B) reduction of high-expressing CD4 cells and an increase of low-expressing CD4 cells (by a factor of 5). The reduction of high-expressing cells correlates with the increase of low-expressing cells. Summing up the amounts of high- and low-expressing CD4 cells at time point $48 \mathrm{~h}$ leaves the total amount of all $\mathrm{CD}^{+}$cells unchanged. Therefore, we conclude from these experiments that our chimeric anti-CD4 mAbs induce modulation of the CD4 antigen rather than elimination of CD4-expressing cells.

\section{A}

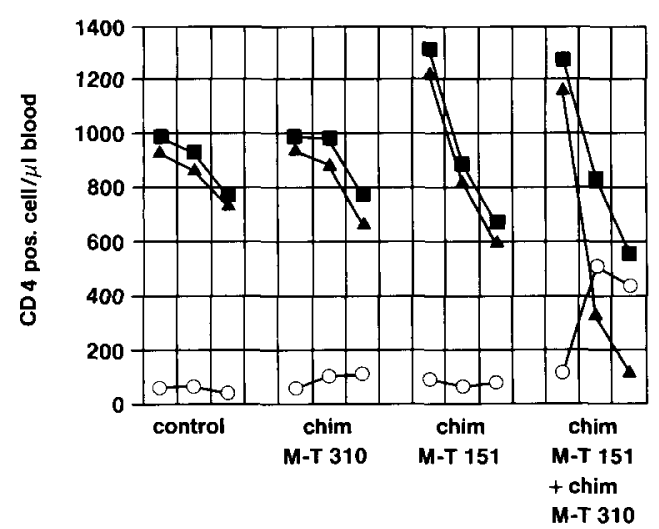

B

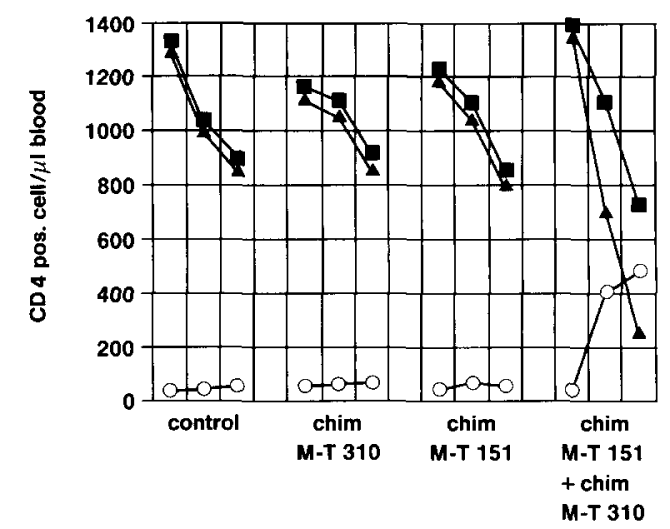

Fig. 4. Immunomodulation by chimeric CD4 mAbs. Reduction of total and high CD4-expressing cells as well as increase of low CD4-expressing cells are shown by the different graphs after incubation of whole blood cells with chimeric mAbs or combinations thereof. In graphs $\mathbf{A}$ and $\mathbf{B}$ blood of two different donors was analysed. Total, high and low CD4-expressing cells were determined at the beginning of the experiment and at 24 and $48 \mathrm{~h}$ after incubation with the mAbs, respectively. Filled squares represent total CD4 cells, filled triangles high CD4-expressing cells, and open circles display low CD4-expressing cells. Methods. $100 \mu \mathrm{l}$ of whole heparin-treated blood was cocultured with chimeric anti-CD4 $\mathrm{mAb}(100 \mu \mathrm{g} / \mathrm{ml})$ at $37^{\circ} \mathrm{C}$ in flat-bottom microtiter plates in duplicates. At time points 0,24 and $48 \mathrm{~h}$, the amount of $\mathrm{CD} 4^{+}$cells was determined by FACscan analysis with the FITC-conjugated mAb OKT4 (Ortho). $\mathrm{CD}^{+}$cells have been determined in total as well as grouped into low and high CD4-expressing cells according to their fluorescence intensity. For flow cytometry $10^{5}$ FITC-labelled CLL cells (plus $10 \mu \mathrm{g} / \mathrm{ml}$ propidium bromide) were added to each sample as the standard cell population. Total $\mathrm{CD} 4{ }^{+}$cells were determined relative to the amount of detected standard cells. There is no cross-blocking of the chimeric Abs by OKT4. 
TABLE I

Dose-dependent inhibition of MLR by individual chimeric mAbs

\begin{tabular}{rlcc}
\hline $\begin{array}{l}\text { mAb concentrations } \\
(\mathrm{ng} / \mathrm{ml})\end{array}$ & \multicolumn{3}{l}{ Inhibition of $\mathrm{MLR}^{\mathrm{a}}(\%)$} \\
\cline { 2 - 4 } & MAK 179 & M-T310 & M-T151 \\
\hline 1 & 4 & 9 & 5 \\
3 & 11 & 18 & 2 \\
10 & 28 & 26 & 24 \\
30 & 48 & 57 & 52 \\
100 & 58 & 58 & 54 \\
300 & 61 & 67 & 67 \\
1000 & 61 & 68 & 67 \\
30000 & 61 & 70 & 70 \\
\hline
\end{tabular}

a Methods. Human PBL were isolated from a single healthy donor by elutriation (Red Cross, Munich, FRG) followed by discontinuous gradient centrifugation with lymphocyte separation medium (Boehringer Mannheim, Germany). Cells at the interphase were collected and washed twice with RPMI 1640 (supplemented with $10 \%$ fetal calf serum $/ 2 \mathrm{mM}$ glutamine $/ 1 \% \mathrm{BME}$ vitamins $/ 100 \mu \mathrm{g}$ penicillin $/ 100 \mu \mathrm{g}$ streptomycin, all per ml, from Boehringer Mannheim, Germany. Then $10^{7}$ stimulator cells (human lymphocyte cell line RPMI 1788, ATCC CCL 156) were treated for $45 \mathrm{~min}$ at $37^{\circ} \mathrm{C}$ and $5 \% \mathrm{CO}_{2}$ in a volume of $1 \mathrm{ml}$ with $50 \mu \mathrm{g}$ mitomycin C/ml. After centrifugation, cells were washed twice with RPMI 1640 and adjusted to a cell titer of $10^{6} \mathrm{cells} / \mathrm{ml}$. MLR was performed by co-culturing $10^{5} \mathrm{PBL} / 100 \mu \mathrm{l}$ with the same amount of stimulator cells in flat-bottom microtiter plates (Nunc). The mAbs were added either alone or in combination in a $20 \mu \mu$ volume to give the final concentration as indicated in the table. The allogeneic response was assayed on day four by pulsing the cells with $0.5 \mu \mathrm{Ci}\left[{ }^{3} \mathrm{H}\right.$ ]-thymidine $(25 \mathrm{Ci} / \mathrm{mM}$, Amersham Buchler). After $18 \mathrm{~h}$ the cultures were terminated by harvesting the cells on glassfiber filters, and the amount of radioactivity incorporated into the cellular DNA was determined with the filter counting system INB-384 (Inotech, Wohlen, Switzerland).

All assays were done in triplicates and the results expressed as:

$1-\left(\frac{\mathrm{cpm}_{\text {experiment }}-\mathrm{cpm}_{\text {background }}}{\mathrm{cpm}_{\text {positive controt }}-\mathrm{cpm}_{\text {background }}}\right) \times 100=\%$ inhibition in MLR

where $\mathrm{cpm}=$ counts per $\min ; \mathrm{cpm}_{\text {experiment }}$ is the MLR response with mAbs; $\mathrm{cpm}_{\text {pasitive }}$ control is the MLR response without mAbs; $\mathrm{cpm}_{\text {background }}$ represents the spontaneous proliferation of responder cells.

$\Lambda \mathrm{nti}-\mathrm{CD} 4 \mathrm{~m} \Lambda \mathrm{b}$ has the potential to modulate the function of $\mathrm{CD}^{+}$cells either by delivering an inactivating signal (Rosoff et al., 1987) or by inhibiting the association of the $\mathrm{CD} 4$ molecule with the $\mathrm{T}$ cell receptor-CD3 complex or by blocking its interaction with MHC class II molecules on cooperating cells. In vivo experiments have shown that the immunosuppressive effect and the induction of tolerance by anti-CD4 mAbs does not entirely depend on cell depletion (Benjamin et al., 1988; Alters et al., 1990; Cobbold et al., 1990; Qin et al., 1990). Furthermore it has been shown that Fab fragments of an anti-CD4 mAb mediate immunosuppression (Carteron et al., 1988). Qin et al. (1987) have demonstrated an improved clearance of cells in vivo and tolerance induction, using synergistic pairs of anti-CD4 mAbs.
TABLE II

Inhibition of MLR by selected combinations of mAbs

\begin{tabular}{|c|c|c|c|c|}
\hline \multicolumn{4}{|c|}{$\mathrm{mAb}$ concentrations $(\mathrm{ng} / \mathrm{ml})^{\mathrm{a}}$} & \multirow{2}{*}{$\begin{array}{l}\text { Inhibition of } \\
\text { MLR }(\%)\end{array}$} \\
\hline M-T310 & M-T151 & MAK 179 & MAK 215 & \\
\hline 1 & & & & 6 \\
\hline 10 & & & & 38 \\
\hline \multirow[t]{8}{*}{100} & & & & 59 \\
\hline & 1 & & & 0 \\
\hline & 10 & & & 29 \\
\hline & 100 & & & $\$ 7$ \\
\hline & & 1 & & 0 \\
\hline & & 10 & & 23 \\
\hline & & 100 & & 53 \\
\hline & & & 10000 & 5 \\
\hline 1 & 100 & & & 65 \\
\hline 10 & 100 & & & 64 \\
\hline 100 & 100 & & & 60 \\
\hline 100 & 1 & & & 58 \\
\hline 100 & 10 & & & 58 \\
\hline 100 & 100 & & & 60 \\
\hline 100 & & 1 & & 59 \\
\hline 100 & & 10 & & 69 \\
\hline \multirow[t]{4}{*}{100} & & 100 & & 92 \\
\hline & 100 & 1 & & 58 \\
\hline & 100 & 10 & & 64 \\
\hline & 100 & 100 & & 96 \\
\hline \multirow[t]{2}{*}{100} & & & 10000 & 40 \\
\hline & 100 & & 10000 & 45 \\
\hline
\end{tabular}

* The mAbs used are chimeric ( $\operatorname{IgG} 1)$, with the exception of MAK215. This $\mathrm{mAb}\left(\operatorname{IgG}_{2 \mathrm{~b}}\right)$ is directed against the $x$ chain of the IL $2 \mathrm{R}$ and does not compete with IL2 binding (unpublished observations).

For methods see Table I.

\section{(e) Inhibition of MLR}

When lymphocytes from two genetically different individuals of a specics arc mixed in ccll culture medium, thc $T$ cells of each individual respond to the MHC antigens of the other by differentiation and proliferation. This process is called mixed lymphocyte reaction (MLR). Allogeneic antigens presented on accessory cells stimulate precursor cells, and the effector cells secrete IL2 and other lymphokines that cause maturation of effector $T$ cells. Since these mechanisms are responsible for allograft rejection, it is of great interest to suppress $\mathrm{T}$-cell reactivity in allograft patients. In the present study we demonstrate that each chimeric anti-CD $4 \mathrm{mAb}$ by itself inhibits markedly MLR. This can also be achieved by the anti-IL2R $\alpha$ mAb MAK 179. As shown in Table I, a dose-dependent inhibition of the MLR up to a concentration of $300 \mathrm{ng} / \mathrm{ml}$ can be obtained with these three mAbs. The maximum inhibition of MLR is 
about $60-70 \%$. An increase of the mAb concentration to $30 \mu \mathrm{g} / \mathrm{ml} \mathrm{did} \mathrm{not} \mathrm{result} \mathrm{in} \mathrm{any} \mathrm{further} \mathrm{increase} \mathrm{in} \mathrm{inhibition.}$ Probably, the proliferation of lymphocytes is supported by additional signals, besides those mediated by CD4 and IL2R.

For clinical applications it is important to accomplish a high degree of suppression of T-cell proliferation. In Table II we show that a combination of the chimeric anti-CD4 mAbs M-T310 and M-T151 did not lead to a marked increase in MLR inhibition; however, either of the anti-CD4 mAbs (M-T310 or M-T151) in combination with the antiIL2R $\propto$ mAb MAK 179 mediates an almost $100 \%$ inhibition of MLR, using each $\mathrm{mAb}$ in a concentration of $100 \mathrm{ng} /$ $\mathrm{ml}$. The combination of each anti-CD4 $\mathrm{mAb}$ and another anti-IL2R $\alpha$ mAb M215, which does not compete with binding of IL2 to its receptor (unpublished observations), did not show any synergistic effect, even when used at a concentration of $10 \mu \mathrm{g} / \mathrm{ml}$ (data not shown). In addition, even at reduced concentrations $(10 \mathrm{ng} / \mathrm{ml}$ of each $\mathrm{mAb}$ ) the combination of either one of the two anti-CD4 mAbs and the anti-IL2R $\alpha$ mAb MAK 179 resulted in almost $50 \%$ inhibition of the MLR.

These data show that an inhibition of the MLR can be achieved very effectively by the combined administration of one of the two anti-CD4 mAbs and the anti-IL2R $\alpha \mathrm{mAb}$ MAK 179. During treatment of autoimmune diseases and following organ transplantation, $\mathrm{mAbs}$ are administered in doses ranging from 20 to $50 \mathrm{mg}$ per day. By using an anti$\mathrm{CD} 4 / \mathrm{IL} 2 \mathrm{R} \alpha \mathrm{mAb}$ cocktail, we assume that the same immunosuppressive effect might be obtained by a 5-10 times lower dose than when using either one alone.

\section{(f) Conclusions}

(1) We were able to establish transfectomas with Igspecific mRNA steady state levels comparable to those of the original hybridoma cell lines with our cloning/ expression system. The mRNA steady state levels correlated with the secretion of reconstituted mAb into the culture supernatants.

(2) Selective T-cell-targeted therapy is an attractive alternative to non-specific immunosuppressive drugs in the treatment of graft rejections as well as autoimmune disorders. The chimerization of mAbs reduces their immunogenicity (Brüggemann et al., 1989) for serotherapy in humans, it enhances the serum half-life and improves physiological effector functions (reviewed by Waldmann, 1991b).

(3) Chimeric mAbs M-T151 and M-T310 seem to be suitable for the therapy of autoimmune diseases. The murine mAb M-T151 has been already used successfully in a limited trial (Herzog et al., 1987). Complement activation and antigen modulation are only performed by a combination of the chimeric anti-CD4 $\mathrm{mAb}$; the individual mAbs do not display these properties. Therefore, we suggest that a combination of both chimeric mAbs is more effective than the administration of a single mAb.

(4) For the treatment of graft rejections, a combination of an anti-IL2R $\alpha$-chain mAb and an anti-CD4 mAb seems to be a very effective combination, as T-cell proliferation can be almost completely suppressed.

(5) Our study shows that combinations of mAbs are more effective than single mAbs with respect to several properties (complement activation, CD4 modulation, inhibition of MLR). Cocktails of mAbs containing anti-CD4 $\mathrm{mAbs}$ and/or IL2R $\alpha \mathrm{mAbs}$ and also mAbs directed to other $\mathrm{T}$-cell accessory molecules should provide new tools for immunotherapy.

\section{ACKNOWLEDGEMENTS}

We would like to thank Christine Federle for excellent technical assistance, and B. Totzek for typing the manuscript. This work was partly supported by the Genzentrum, Munich, Germany.

\section{REFERENCES}

Alt, F. and Baltimore, D.: Joining of immunoglobulin heavy chain segments: implications from a chromosome with evidence of three D-JH fusions. Proc. Natl. Acad. Sci. USA 79 (1982) 4118-4122.

Alters, S.E., Sakaj, K., Steinman, L. and Oi, V.T.: Mechanism of anti CD4 mediated depletion and immunotherapy. A study using a set of chimeric anti CD4 antibodies. J. Immunol. 144 (1990) 4587-4592.

Ashkenazi, A., Presta, L.G., Marsters, S.A., Camerato, T.R., Rosenthal, K.A., Fendly, B.M. and Capon, D.J.: Mapping the CD4 binding site for human immunodeficiency virus by alanine-scanning mutagenesis. Proc. Natl. Acad. Sci. USA 87 (1990) 7150-7154.

Auffray, C. and Rougeon, F.: Purification of mouse immunoglobulin heavy chain messenger RNA from total myeloma tumor RNA. Eur. J. Biochem. 107 (1980) 303-314.

Benjamin, R.J., Quin, S.X., Wise, M.P., Cobbold, S.P. and Waldmann, H.: Mechanisms of antibody-facilitated tolerance induction: a possible role for the CD4 (L3T4) and CD11a (LFA-1) molecules in selfnon-self discrimination. Eur. J. Immunol. 18 (1988) 1070-1088.

Bindon, C.I., Hale, G., Clark, M. and Waldmann, H.: Therapeutic potential of monoclonal antibodies to the leukocyte-common antigen. Synergy and interference in complement-mediated lysis. Transplantation 40 (1985) 538-544.

Brodeur, P. and Riblet, R.: The immunoglobulin heavy chain variable region locus in the mouse: one hundred Igh-V genes comprise seven families of homologous genes. Eur. J. Immunol. 14 (1984) 922-930.

Brüggemann, M., Williams, G.T., Bindon, G.I., Clark, M.R., Walker, M.R., Jefferis, R., Waldmann, H. and Neuberger, M.S.: Comparison of the effector functions of human immunoglobulins using a matched set of chimeric antibodies. J. Exp. Med. 166 (1987) 1351-1361.

Brüggemann, M., Winter, G., Waldmann, H. and Neuberger, M.: The immunogenicity of chimeric antibodies. J. Exp. Med. 170 (1989) 2153-2157.

Cabilly, S. and Riggs, A.: Immunoglobulin transcripts and molecular history of a hybridoma that produces antibody to carcinoembryonic antigen. Gene 40 (1985) 157-161. 
Carteron, N.L., Wofsy, D. and Seaman, W.E.: Induction of immune tolerance during administration of monoclonal antibody L3T4 does not depend on depletion of L3T4+ cells. J. Immunol 140 (1988) $713-716$.

Cobbold, S.P.. Jayasuriya, A., Nash, A., Prospero, T.D. and Waldmann, H.: Therapy with monoclonal antibodies by elimination of $\mathrm{T}$ cell subsets in vivo. Nature 312 (1984) 548-551.

Cobbold, S.P., Martin, G. and Waldmann, H.: The induction of skin graft tolerance in major histocompatibility complex-mismatched or primed recipients: primed $T$ cells can be tolerized in the periphery with antiCD4 and anti-CD8 antibodies. Eur. J. Immunol. 20 (1990) 27452755

Hervé, P., Wijdenes, J., Bergerat, J.P., Bordigoni, P., Milpied, N., Cahn, J.Y., Clément, C., Beliard, R., Morel-Fourrier, B., Racadot, E., Troussard, X., Benz-Lemoine, E., Gaud, C., Legros, M., Attal, N.O., Kloft, M. and Peters, A.: Treatment of corticosteroid resistant acute graft-versus-host disease by in vivo administration of anti-interleukin2 receptor monoclonal antibody (B-B 10). Blood 75 (1990) 1017-1023.

Herzog, C., Walker, C., Pichler, W., Aeschlimann, A., Wassmer, P., Stockinger, H., Knapp, W., Rieber, E.P. and Müller, W.: Monoclonal anti-CD4 in arthritis. Lancet 2 (1987) 1461-1462.

Hughes-Jones, N.C., Gorick, B.D. and Howard, J.C.: The mechanism of synergistic complement-mediated lysis of rat cells by monoclonal IgG antibodies. Eur. J. Immunol. 13 (1983) 635-641.

Kabat, E.A., Wu, T.T., Reid-Müller, M., Perry, H.M. and Gottesman, K.S.: Scquences of Protcins of Immunological Interest, 4 th cd. U.S. Department of Health and Hurnan Services, National Institutes of Health, Bethesda, MD, 1987.

Kaluza, B., Lenz, H., Russmann, E., Hock, H., Rentrop, O., Majdic, O., Knapp, W. and Weidle, U.H.: Synthesis and functional characterization of a recombinant monoclonal antibody directed against the $\alpha$-chain of the human interleukin-2 receptor. Gene 107 (1991) 297305.

Kofler, R., Duchosal, M.A. and Dixon, F.J.: Complexity, polymorphism, and connectivity of mouse $V_{\kappa}$ gene families. Immunogenetics 29 (1989) $65-74$.

Kohler, G. and Milstein, C.: Continuous cultures of fused cells secreting antibody of predefined specificity. Nature 256 (1975) 495-497.

Kurosawa, Y. and Tonegawa, S.: Organization, structure and assembly of immunoglobulin heavy chain diversity DNA segments. J. Exp. Med. 155 (1982) 201-218.

Kyle, V., Coughlan, R.J., Tighe, H., Waldmann, H and Hazleman, B.L.: Beneficial effect of monoclonal antibody to interleukin 2 receptor on activated T cells in rheumatoid arthritis. Ann. Rheum. Dis. 48 (1989) 428-429.

Lifson, J.C. and Engleman, E.G.: Role of CD4 in normal immunity and HIV infection. Immunol. Rev. 109 (1989) 93-117.

Maniatis, T., Fritsch, E.F. and Sambrook, J.: Molecular Cloning. A Laboratory Manual. Cold Spring Harbor Laboratory, Cold Spring Harbor, NY, 1982.

Miller, S.D. and Jenkins, M.K.: In vivo effects of Gk1.5 (anti L3T4a) monoclonal antibody on induction and expression of delayed type hypersensitivity. Cell Immunol. 92 (1985) 414-426.

Morrison, S.L., Johnson, M.J., Herzenberg, L.A. and Oi, V.T.: Chimeric human antibody molecules: mouse antigen binding domains with human constant region domains. Proc. Natl. Acad. Sci. USA 82 (1984) 6851-6855.

Peterson, A. and Seed, B.: Genetic analysis of monoclonal antibody and HIV binding sites on the human lymphocyte antigen CD4. Cell 54 (1988) 65-72.

Qin, S., Cobbold, S., Tighe, H., Benjamin, R. and Waldmann, H.: CD4 monoclonal antibody pairs for immunosuppression and tolerance induction. Eur. J. Immunol. 17 (1987) 1159-1165.

Qin, S.X., Wise, M., Cobbold, S.P., Leong, L., Kong, Y.C., Parnes, J.R. and Waldmann, $\mathrm{H}$.: Induction of tolerance in peripheral $\mathrm{T}$ cells with monoclonal antibodies. Eur. J. Immunol. 20 (1990) $2737-2745$.

Reinke, P., Volk, H.D., Miller, H., Neuhaus, K., Fietze, E., Herberger, J., Herberger, D., von Baehr, R. and Emmrich, F.: Anti-CD4 therapy of acute rejection in long-term renal allograft recipients. Lancet 338 (1991) 702-703.

Reiter, C., Kakavand, B., Rieber, E.P., Schattenkirchner, M., Riethmüller, G. and Kruger, K.: Treatment of theumatoid arthritis with monoclonal CD4 antibody M-T151. Clinical results and immunopharmacological effects in an open study, including repeated application. Arthritis Rheum. 34 (1991) 525-536.

Riechmann, L., Clark, M., Waldmann, H. and Winter, G.: Reshaping human antibodies for therapy. Nature 332 (1988) 323-327.

Rosoff, P.M., Burakoff, S.J. and Greenstein, J.L.: The role of L3T4 molecule in mitogen or antigen activated signal transduction. Cell 49 (1987) 845-853.

Sanger, F., Nicklen, S. and Coulson, A.R.: DNA sequencing with chainterminating inhibitors. Proc. Natl. Acad. Sci. USA 74 (1977) 54635467.

Sattentau, Q.J., Arthos, J., Deen, K., Hanna, N., Healey, D., Beverly, P.C.L., Sweet, R. and Truneh, A.: Structural analysis of the human immunodeficiency virus hinding domain of CD4. I. Exp. Med. 170 (1989) 1319-1334.

Strohal, R., Helmberg, A., Kroemer, G. and Kofler, R.: Mouse V $\kappa$ gene classification by nucleic acid sequence similarity. Immunogenetics 30 (1989) 475-493.

Waldmann, T.A.: The interleukin 2 receptor. J. Biol. Chem. 266 (1991a) 2681-2684.

Waldmann, T.A.: Monoclonal antibodies in diagnosis and therapy. Science 252 (1991b) 1657-1662.

Weissenhorn, W., Weiss, E., Schwirzke, M., Kaluza, B. and Weidle, U.H.: Chimerization of antibodies by isolation of rearranged genomic variable regions by the polymerase chain reaction. Gene 106 (1991) 273-277.

Winter, E., Radbruch, A. and Krawinkel, U.: Members of novel VH families are found in VDJ regions of polyclonally activated B lymphocytes. EMBO J. 4 (1985) 2681-2687. 